\title{
Bayam Merah Untuk Peningkatan Kadar Hemoglobin Remaja Putri Kelas Xii SMK Al-Islam Kudus
}

\author{
Umi Faridah $^{1}$, Subiwati ${ }^{2}$, Rista Ayuningrum ${ }^{3}$ \\ 1. StikesMuhammadiyah Kudus \\ 2. StikesMuhammadiyah Kudus \\ 3. StikesMuhammadiyah Kudus \\ E-mail:umifaridah@stikesmuhkudus.ac.id
}

\begin{abstract}
Abstrak
Latar Belakang: Anemia adalah salah satu masalah gizi utama yang terjadi di Indonesia, khususnya anemia. Anemia menonjol pada masa anak-anak sekolah terutama remaja putri. Remaja putri berisiko tinggi terjadi anemia, karena pada masa remaja terjadi peningkatan kebutuhan zat besi akibat adanya pertumbuhan dan masa menstruasi. Kegiatan di sekolah, perkuliahan maupun berbagai aktifitas organisasi dan ekstrakurikuler yang tinggi akan berdampak pada pola makan yang krang teratur, selain itu kebiasaan mengkonsumsi minuman yang menghambat absorbsi zat besi akan mempengaruhi kadar hemoglobin seseorang. Penelitian ini untuk mengetahui pengaruh pemberian bayam merah sebagai peningkatan kadar $\mathrm{Hb}$ pada remaja putri yang mengalami anemia di SMK Al-Islam tahun 2016. Jenis penelitian ini menggunakan jenis penelitian quasy eksperimental dengan pendekatan prepost test with control grup. Sampel dalam penelitian ini sebanyak 20 responden dengan menggunakan teknik random sampling. Uji statistik yang digunakan wilcoxon signed rank tes dengn nilai $\rho$ value $=0.005$ sehinggasimpulkan ada pengaruh yang signifikan $(\rho$ value $0.005<0,05$ ) bayam merah dalam membantu menaikkan kadar zat besi dalam darah sehingga membantu mencegah anemia. Ada pengaruh pemberian bayam merah sebagai upaya peningkatan kadar hemoglobin pada remaja putri yang mengalami anemia di SMK Al-Islam Kudus tahun 2016.
\end{abstract}

Kata Kunci: BayamMerah; Hemoglobin; Anemia

\section{Red Spinach To Increase Hemoglobin Level for Adolescents On Class XII SMK Al-Islam Kudus}

\begin{abstract}
Background: Anemia is one of the major nutritional problems occurring in Indonesia, especially anemia. Anemia stands out in school children, especially young women. Adolescent girls are at high risk of anemia, because in adolescence there is an increase in iron demand due to growth and menstrual period. High school activities, lectures and organizational activities and extracurricular activities will be an impact on regular eating patterns, as well as consuming beverages that inhibit the absorption of iron will affect a person's hemoglobin levels. The purpose of this study to know the influence of red spinach increasing $\mathrm{Hb}$ level for adolescents who have anemia In Smk Al-Islam Year 2016. Types of this research used experimental quasy research with pre-post test with control groups. sample in this research 20 respondents by used random sampling technique. Statistic sest used wilcoxon signed rank test.wilcoxon signed rank test result obtain value $\rho$ value $=0.005$ so it can be concluded hhere is significant influence ( $\rho$ value $0.005<0.05$ ). Red spinach helps raise iron levels in blood to helps prevent anemia.There is influence of red spinach as efforts to increase hemoglobin levels in young women who have anemia in smk al-islamkudus year 2016.
\end{abstract}

Jurnal SMART Keperawatan Sekolah Tinggi Ilmu Kesehatan (STIKes) Karya Husada Semarang www.stikesyahoedsmg.ac.id/ojs/index.php/sjkp(perawat) 
Keywords: Red Spinach; Hemoglobin; Anemia

Pendahuluan

Anemia merupakan salah satu masalah gizi utama di Indonesia, khususnya anemia defisiensi bezi. Kasus anemia sangat menonjol pada anak-anak sekolah terutama remaja putri. Remaja putri berisiko tinggi menderita anemia, karena pada masa ini terjadi peningkatan kebutuhan zat besi akibat adanya pertumbuhan dan menstruasi. Aktifitas sekolah, perkuliahan maupun berbagai aktifitas organisasi dan ekstrakurikuler yang tinggi akan berdampak pada pola makan yang tidak teratur, selain itu kebiasaan mengkonsumsi minuman yang menghambat absorbsi zat besi akan mempengaruhi kadar hemoglobin seseorang. (Dinkes, 2012).

Masa remaja merupakan masa pertumbuhan dan perkembangan, baik secara fisik, mental, dan aktivitas sehingga, kebutuhan makanan yang mengandung zat-zat gizi menjadi cukup besar. Remaja putri banyak mengalami kekurangan zat-zat gizi dalam konsumsi makanan sehariharinya. Remaja putrid umumnya mengalami kekurangan zat besi, kalsium, dan vitamin A. Di samping itu, juga kekurangan vitamin B6, seng, asam folat, iodium, vitamin D, dan magnesium (Agus, 2009)

Di Indonesia prevalensi anemia pada remaja putri tahun 2005, mencapai 26,50\% (Depkes, 2010). Remaja putrid termasuk golongan rawan menderita anemia karena remaja putri dalam masa pertumbuhan dan setiap bulan mengalami menstruasi yang menyebabkan kehilangan zat besi, kondisi anemia ini sering diabaikan para remaja (Arisman, 2009). Kasus anemia di Indonesia sebagian besar disebabkan oleh kekurangan Fe sehingga disebut juga anemia gizi besi.Oleh karena itu, anemia gizi besi menjadi salah satu fokus dalam perbaikan gizi masyarakat selain defisiensi vitamin A dan Gangguan Akibat Kekurangan Iodium (GAKI) (Kementerian Kesehatan RI, 2011).

Anemia dapat menyebabkan cepat lelah, konsentrasi belajar menurun sehingga prestasi belajar rendah dan dapat menurunkan produktivitas kerja pada remaja. Anemi juga dapat menurunkan daya tahan tubuh sehingga mudah terkena infeksi. Prevalensi anemia yang tinggi pada remaja jika tidak tertangani dengan baik akan berlanjut hingga dewasa dan berkontribusi besar terhadap angka kematian ibu, bayi lahir prematur, dan bayi dengan berat lahir rendah (Robertus, 2014).

Menurut World Health Organization (WHO) secara global prevalensi defisiensi besi di 
negara berkembang dua sampai lima kali prevalensi anemia. Organisasi WHO menyatakan anemia mempengaruhi 1,62 juta orang di dunia (24,8\%) ( Johnson-Wimbley \& Graham, 2011).

Data Riskesdas pada tahun 2013 menunjukkan bahwa proporsi anemia berdasarkan karakteristik usia yaitu $12-59$ bulan $28,1 \%, 5-14$ tahun $26,4 \%$, dan 15-24 tahun 18,4\%. Serta $22,7 \%$ terjadi pada perempuan tidak hamil dan $37,1 \%$ terjadi pada perempuan hamil. Prevalensi anemia gizi besi secara nasional pada remaja usia 13-18 tahun sebesar 22,7\%. Data-data tersebut mengindikasikan bahwa anemia merupakan masalah kesehatan pada remaja yang terjadi pada masyarakat di Indonesia.

Berdasarkan data dari Puskesmas Rendeng Tahun 2015, didapatkan data anemia remaja putri di SMK Farmasi dari 100 siswi putri didapatkan 51 orang terkena anemia. Namun saat ini belum pernah dilakukan skrinning anemia pada remaja maupun siswi diseluruh sekolah di Kabupaten Kudus.

Salah satu makanan untuk meningkatkan kadar hemoglobin dalam darah salah satunya adalah rebusan bayam merah. Bayam merah merupakan salah satu tanaman alternatif dalam pemenuhan kebutuhan zat besi pada remaja yang mengalami anemia. (Purnawijayanti, 2009), juga menyebutkan bahwa bayam merah mengandung karotenoid dan flavonoid yang merupakan zat aktif dengan khasiat antioksidan. Jenis karotenoid utama dalam bayam merah adalah beta karoten, sedangkan zat aktif lainnya adalah klorofil. Jenis flavonoid yang terkandung di dalam bayam merah adalah lutein dan kuersetin. Kuersetin merupakan antioksidan kuat yang mampu menangkap radikal bebas superoksida dan menghambat oksidasi kolesterol LDL.

\section{Metode Penelitian}

Jenis penelitian ini adalah Quasy Eksperimental dengan menggunakan bentuk rancangan control group pre test-post test.

Populasi adalah seluruh subjek (manusia, binatang percoban, data laboratorium, dll ) (Riyanto, 2011).

Populasi dalam penelitian ini adalah seluruh remaja putri kelas XII SMK Al Islam Kudus. Sampel dalam penelitian ini yaitu kelas XII SMK Al Islam Kudus. Teknik pengambilan sample yang digunakan adalah random sampling, yaitu cara pengambilan sample dengan mengambil secara acak dari populasi yang ada (Saryono dan Setiawan, 2010). 
Dalam rancangan ini kelompok eksperimental diberi perlakuan berupa pemberian bayam sedangkan kelompok control tidak diberikan perlakuan apapun. Pada kelompok eksperimental dan control diawali dengan pre-test (pengukuran awal) pengecekan kadar $\mathrm{Hb}$ pada remaja putrid dan setelah pemberian perlakuan diadakan pengecekan kembali (post-test). Analisa data pada penelitian ini menggunakan uji. Uji ini Wilcoxon Signed Rank Test digunakan untuk membandingkan perbedaan dua media jika populasi tidak berdistribusi normal.

\section{Hasil Penelitian}

Tabel 1 Distribusi Frekuensi Karakteristik Responden Berdasarkan Umur Siswa Kelas XII JurusanFarmasi SMK Al Islam Kudus (N=20) Tahun 2016

\begin{tabular}{lcr}
\hline Usia & Frekuensi & Prosentasi (\%) \\
\hline$<15$ & 1 & $5 \%$ \\
$15-16$ & 2 & $10 \%$ \\
$>16$ & 17 & $85 \%$ \\
\hline Total & 20 & $100 \%$ \\
\hline
\end{tabular}

Tabel 2 Distribusi Frekuensi Berdasarkan Mean, Median, dan Modus Kelompok Kontrol dan Intervensi Sebelum dan Sesudah Pemberian Bayam Merah Penderita Anemia Kelas XII Di SMK Al-Islam Kudus Tahun 2016

\begin{tabular}{lllcccr}
\hline Kelompok & Variabel & Mean & Median & Modus & Min & Max \\
\hline \multirow{2}{*}{ Kontrol } & Pre & 10,57 & 10,60 & 10 & 10 & 12 \\
& Post & 10,59 & 10,60 & 10 & 10 & 12 \\
\hline \multirow{2}{*}{ Intervensi } & Pre & 10,30 & 10,15 & 10 & 10 & 11 \\
& Post & 10,89 & 10,75 & 11 & 10 & 12 \\
\hline
\end{tabular}

Tabel 3 Perbandingan rata-rata Kadar Hb Kelompok Kontrol Dan Intervensi Sebelum Dan Sesudah Pemberian Bayam Merah Pada Penderita Anemia Kelas XII Di SMK Al-Islam Kudus Tahun 2016

\begin{tabular}{lcccc}
\hline Variabel & N & Mean & SD & $\rho$ value \\
\hline Kadar hbkelintervensi & & & & \\
Sebelumterapi & 10 & 10,30 & 600 & \\
Sesudahterapi & 10 & 10,89 & 526 & 0,005 \\
Kadar hbkel control & & & & \\
Sebelumterapi & 10 & 10,57 & 690 & \\
Sesudahterapi & 10 & 10,59 & 685 & 0,157 \\
\hline
\end{tabular}

Berdasarkan Hasil Uji Wilcoxon didapatkan bahwa selisih perbandingan rata-rata kadar $\mathrm{Hb}$ pada kelompok intervensi adalah 0,59. Sedangkan selisih perbandingan rata-rata kadar Hb pada kelompok control adalah 0,02. Diperoleh $\rho$ value sebesar 0,005, hal ini menunjukkan bahwa nilai $\rho$ value $<0,05$. Maka dapat disimpulkan bahwa Ha diterima dan H0 ditolak, yaitu ada pengaruh 
bayam merah terhadap peningkatan kadar $\mathrm{Hb}$ pada remaja putri yang mengalami anemia kelas XII di SMK Al-Islam Kudus Tahun 2016

\section{Pembahasan}

Pada hasil umur diperoleh sejumlah mayoritas responden yang mengalami anemia adalah umur >16 tahun berjumlah 17 responden (85\%), umur 15-16 sejumlah 2 responden (10\%), umur $<15$ tahun sejumlah 1 responden $(5 \%)$.

Remaja putri adalah salah satu kelompok yang rawan menderita anemia. Remaja putrid berisiko lebih tinggi terkena anemia dibandingkan dengan remaja laki-laki karena alas an pertama remaja perempuan setiap bulan mengalami siklus menstruasi dan yang kedua yaitu karena memiliki kebiasaan makan yang salah, hal ini terjadi karena para remaja putrid ingin langsing untuk menjaga penampilannya sehingga mereka berdiet dan mengurangi makan, akan tetapi diet yang dijalankan merupakan diet yang tidak seimbang dengan kebutuhan tubuh sehingga dapat menyebabkan tubuh kekurangan zat-zat penting seperti zat besi (Arisman, 2010).

Pada penelitian ini telah dilakukan pada 20 responden di SMK Al-Islam Kudus mengenai pemberian bayam merah dimana 10 responden menjadi kelompok intervensi yang diberi perlakuan (50\%) dan 10 responden menjadi kelompok control yang tidak diberi perlakuan (50\%). Hasil menunjukkan peningkatan kadar $\mathrm{Hb}$ dari 10,30 gr/dl menjadi 10,89 gr/dl.

Berdasarkan hasil penelitian didapatkan dari hasil uji Wilcoxon yaitu $\rho$ value $0,005(<\alpha$ 0,05) yang bahwa Ha diterima dan Ho ditolak, yaitu ada pengaruh bayam merah terhadap peningkatan kadar $\mathrm{Hb}$ pada remaja putri yang mengalami anemia kelas XII di SMK Al - Islam Kudus.

Salah satu makanan untuk meningkatkan kadar hemoglobin dalam darah salah satunya adalah rebusan bayam. Bayam merupakan salah satu tanaman alternative dalam pemenuhan kebutuhan zat besi pada remaja yang mengalami anemia. Penelitian ini sejalan dengan hasil penelitian yang dilakukan oleh KH Endah Widhi Astuti tahun 2015 menunjukkan bahwa Mengkonsumsi Rebusan Bayam Merah dapat mengatasi anemia pada ibu hamil. Bayam merah banyak mengandung protein, lemak, karbohidrat, kalium, kalsium, mangan, fosfor, zat besi, amarantin, rutin, purin, niasindan vitamin (A,B1,B2,C), karotin, klorofil dan saponin. (Faralia, 2012). Zat besi merupakan mineral yang diperlukan untuk mengangkut oksigen keseluruh tubuh. Kekurangan zat besi dalam tubuh bias membuat seseorang mengalami 
penurunan sistem kekebalan tubuh dan sering merasa lesu. Hal ini juga merupakan salah satu penyebab anemia.

Anemia adalah kekurangan kadar hemoglobin (Hb) dalam darah yang disebabkan kekurangan zat gizi yang diperlukan untuk pembentukan hemoglobin. Kadar Hb normal pada remaja perempuan adalah 12 gr/dl. Remaja dikatakan anemia jika kadar $\mathrm{Hb}<12$ gr/dl (Proverawati \& Asfuah, 2009). Anemia dapat menyebabkan lekas lelah, konsentrasi belajar menurun sehingga prestasi belajar rendah dan dapat menurunkan produktivitas kerja. Prevalensi anemia yang tinggi dikalangan remaja jika tidak tertangani dengan baik akan berlanjut hingga dewasa dan berkontribusi besar terhadap angka kematian ibu, bayi lahir prematur, dan bayi dengan berat lahir rendah (Robertus, 2014).

\section{Kesimpulan}

Berdasarkan penelitian dan teori dapat disimpulkan bahwa ada pengaruh bayam merah terhadap kadar $\mathrm{Hb}$ pada remaja putri yang mengalami anemia di kelas XII SMK Al - Islam Kudus tahun 2016.

\section{Saran}

Diharapkan bagi remaja dapat mengetahui gambaran pengaruh pemberian bayam merah untuk meningkatkan kadar haemoglobin pada penderita anemia.

\section{Daftar Pustaka}

Adriani, M. W. (2012). Pengantar Gizi Masyarakat. Jakarta: Kencana.

Adriani, M., \& Wirjatmadi, b. (2012). Pengantar Gizi Masyarakat. Jakarta: Kencana.

Agus, S. (2009). Tetap langsing dan Sehat dengan Terapi Diet. Agromedia pustaka Jakarta.

Arisman, M. (2009). Buku Ajar Ilmu Gizi dalam Daur kehidupan. Jakarta: EGC..

Bidasari, L. (2008). Pencegahan Anemia Defisiensi Besi Sejak Bayi Sebagai Salah Satu Upaya Optimalisasi Fungsi Kognitif Anak Pada Usia Sekolah.

Fraser M. Diane, C. A. (2009). Buku ajar bidan. Jakarta: EGC..

Faralia.(2012). Keajaiban antioksidan bayam. Penerbit: PT Alex Media Komputindo. Hidayat, A. A. (2007). Metode Penelitian dan Teknik Analisis Data. Jakarta: Salemba Medika. 
Isgianto, A. (2009). Teknik Pengambilan Sample. Yogyakarta: Mitra Cendikia Press.

Kusmiran, E. (2011). Kesehatan Reproduksi Remaja dan Wanita. Jakarta: Salemba Medika.

Masrizal. (2007). Anemia Defisiensi Besi. Jurnal Kesehatan Masyarakat .

Notoatmodjo, S. (2005). Metodologi Penelitian Kesehatan. Jakarta: PT. Rineka Cipta.

Notoatmodjo, S. (2010). Metodologi Penelitian Kesehatan. Jakarta: Rineka Cipta.

Notoatmodjo, S. (2010). Promosi Kesehatan dan Ilmu Kesehatan. Jakarta: PT Rineka Cipta.

Nursalam. (2011). Konsep dan Penerapan Metodologi Penelitian Ilmu Keperawatan, Edisi 11. Jakarta: Salemba Medika.

Nursalam. (2011). Konsep dan Penerapan Metodologi Penelitian Ilmu Kesehatan Pedoman Skripsi, Thesis, dan Instrumen Penelitian Keperawatan. Jakarta: Salemba Medika.

Proverawati. (2011). Ilmu Gizi untuk Perawat dan Gizi Kesehatan. Yogyakarta: Yulia Medika.

Proverawati, A., \& Asfuah, S. (2009). Gizi Untuk Kebidanan. Yogyakarta: Nuha Medika.

Purnawijayanti. (2009). Mie Sehat. Yogyakarta.

Riwidikdo, H. (2009). Statistik Untuk Penelitian Kesehatan dengan Aplikasi Program $R$ dan SPSS. Yogyakarta: Pustaka Rihama.

Riyanto, A. (2011). Aplikasi Metodologi Penelitian Kesehatan. Yogyakarta: Nuha Medika.

Rukmana, R. (2006). Bayam, Bertanam dan Pengolahan Pascapanen. Yogyakarta: Kanisius.

Sarwono, S. W. (2011). Psikologi Remaja. Edisi Revisi. Jakarta: Rajawali Pers.

Saryono. (2010). Metodologi Penelitian Kesehatan Penuntun Praktis Bagi Pemula. Jogjakarta: Mitra Cendikia.

Saryono, S. (2010). Metodologi Peneltian Kebidanan DIII, D IV, S1, Dan S2. Yogyakarta: Nuha Medika.

Sugiyono. (2010). Metode Penelitian Administrasi. Bandung: CV. Alfabeta.

Widoyoko, E. (2012). Teknik Penyusunan Instrumen Penelitian. Yogyakarta: Pustaka Pelajar.

Widyastuti, Y. (2009). Kesehatan Reproduksi. Jakarta: Bumi Aksara. 